\title{
TEŞKİLÂT-I MAHSÛSA VE CERMEN ESİR KAMPLARINDAKİ TATARLAR
}

\author{
Dr. Vahdet KELESYYILMAZ
}

I. Dünya Savaşı esnasında gerek Kırım gerek Kazan ve gerekse Sibirya Tatarlanı arasından Rus ordusuna alınmış askerler vardı. Ruslar tarafindan özellikle Alman ve Avusturya-Macaristan ordulanna karşı savaşılan cephelere sevk edilen Tatar askerlerden on binlercesi esir düşmüştür. Almanya'nın Wünsdorf ve Avusturya'nın Eger kamplarında esaret hayatı yaşayan bu askerlerle ilgili mühim faaliyetler gerçekleştirilmiştir. Bu faaliyetlerin en önemlisi ise Tatarların Türkiye'ye getirtilmesi yolundaki çalışmalardır*. Tatarların -kendi nzzalanyla- Osmanlı ordusunda gönüllü olarak istihdamı ya da göçmen olarak Türk topraklarına yerleştirilmelerini hedef alan ve uluslararası ilişkiler açısından büyük önem taşıyan Türk yaklaşımı soydaşlanında makes bulmuşsa da istenilen her şey arzu edildiği gibi gerçekleştirilememiştir.

Burada esas olarak yukanda belirtilen konu aydınlatılmaya çalışılacak olmakla birlikte esir kamplanındaki diğer unsurlara ve önemli gelişmelere de ilgili bağlamdaki faaliyetler ekseninde değinilecektir.

Tatar esirlere yönelik çalışmaların başlangıcını 1915 yılı bahar aylarına kadar götürmek mümkündür. Bu yolda Osmanlı Devleti'nin de içinde bulunduğu grup tarafından yapılan faaliyetlere 1 şı tutan bir rapor, Hâlim Sâbit ${ }^{1}$ Bey tarafından Enver Paşa'ya sunulmuştur. Hâlim Sâbit

* Osmanlı Devleti'nin cöküşs süreci sonrasında Türkiye'de kurulacak olan "seküler ulus-devlet"in gerek düşünsel zemininin oluşturulmasında ve gerekse inşa sürecinde -diğer iç ve dış dinamiklerin yanı sıra- Türk Dünyası aydınlarının (II. Meşrutiyet devrinde Türk Yurdu'nun çıarılmasından Atatürk döneminde Türk Tarih Kurumu başkanlığına uzayan hayat çizgisiyle temayüz eden Yusuf Akçura örneğiyle de anlaşlacağı üzere) önemli bir rolü vardır. Bundan dolayı, bu satırların yazarı -işlenen konuyla ve/veya dönemle ilgili bilinmeyen ayrıntıların gün ıṣığına çıkanlmasıyla yapılacak makro tarih çalışmalarına da mühim bir katkı sağlanabileceği ve böylece varılabilecek sonuçlanın daha sağlıklı olabileceği beklentisiyle- Türkiye'nin yakın tarihi ve uluslararası ilişkiler açısından bir hayli önem taşıyan ilgili bağlamdaki "mikro-ampirik" tarih çalışmalarına devam edecektir.

1. Vahdet Keleşyılmaz, "Birinci Dünya Savașı'nda Esir Askerler Uzerinde Panislamizm Propagandası Teşebbüsü", Kebikeç, S. 10 (2000), s. 31-37. 
rargâhı olan Eger beldesine gelip ifa-yı vazifeye basladık" ${ }^{\prime}$ sözleriyle bu ülkedeki esirlere yönelik faaliyetlerin de ihmal edilmediğini ortaya koymaktadir.

Kazanlı Osman Kadı'nın 14 Oktobr 1915 tarihli yazışmasında "Defaatle Berlin'den mektub gönderdik. Ulaşıyor mu? Cevaba nâil olamad $l . "{ }^{10}$ ifadesi, Almanya ve Avusturya'da gerçekleştirilen faaliyetlerle ilgili iletişimin sağlanmasında kimi güçlükler yaşanmış olabileceğini ortaya koymaktadır.

Kazanlı Osman ve Alimcan İdris'in şahsında değindiğimiz kişiler üstlendikleri görevi ifaya çalışırlarken bu sırada Abdürreșid İbrahim -belki de istediği ödeneğin ulaştırılmasında sorun çıktığından dolayı- İstanbul'a dönmüs olmalıdır. Çünkü 1 Teşrin-i Sani 1915 tarihinde Sefir Hakkı tarafından Harbiye Nezareti'ne gönderilen şifre, bu sırada Abdürreşid İbrahim'in hem İstanbul'da olduğunu ve hem de kendisinden vaz geçilmesi kolay bir kişi olmadığını ortaya koymaktadır:

"Üsera-yı Islâmiyenin Dersaadet'e sevki takarrüb ettiğinden şimdiye kadar icra ettiği makul propogandaya devam etmek üzere Şeyh Abdürreşid Efendi' nin serien buraya izamı." 11

Maddî konularda sıkıntıya düşen yalnızca Abdürreşid İbrahim değildir. İki üç aydan beri Müslüman esirler arasında faaliyet göstermekte olan diğer kişilerin de benzer sıkıntılar çektiği anlaşılmaktadır:

\section{"Efendim hazretleri}

Ellerinizden öperiz. Acizleri iki üç mahtan beri üsera-yı Islâmiye meyaninda... talim ve sair propaganda ile mesgul olmakta isek de Dersaadet'te bulunan ahal ve ailemize bu taraftan para gönderemiyoruz. Zira burası bizim hesab ettiğimiz gibi değildir. Ü̧̧ yüz mark ile ancak kendimizi idare etmekte olduğumuzdan aileler için lütuf buyrulursa acizleri de din ve millet uğrunda say ve gayretimizi bir kat daha artıracăğımızl..."

Daha önce yazışmalanına cevap alamadığını dile getirmiş olan Osman Kadı 16 November (Kasım) 1915 tarihli bir yazısında,

9. K: $1846, \mathrm{D}: 83, \mathrm{~F}: 1 / 21,1 / 23-25$ (Alimcan Idris'in belirttiği adres ise şöyledir: Kriegs Gefangenen Lagers Eger Böhmen).

10. K: $1846, \mathrm{D}: 83$, F: $1 / 20$.

11. K: 1846, D: 83, F: 1/27 (Kırmızı kalemle "manzur buyruldu. Ali Bey Başhama'ya" derkenarı vardır. Ancak bu derkenarın yanında her hangi bir tarih görülemediğinden ve 1 Teşrin-i Sani ile 1331 değil de 1915 tarihine yer verilmesinden tarihin efrenci olup olmadığı kesin olarak anlaşılamamıştır. Tarih efrenci ise 1 Kasım 1915e değilse 14 Kasım 1915e karşılık gelmektedir).

12. K: 1846 , D: 83, F: 1/28 (1915 yılı Kasım ayında "Harbiye Nezareti'nde Bașhamba Ali Beyefendi Hazretlerine" gönderilmiş olan bu mektubun altında -muhtemelen adı geçen ailelerin barınmakta olduğu- üç adres vardır. Bu adreslerden biri Şehremeni civarında Ibrahim Çavus mahallesinde Kaşıkçı Mektebi sokağında 5 numaralı hanedir. Bir diğer adres ise Şehremeni'de Caferağa mahallesinde Saray sokağında 110 numaralı hanedir). 
"Vazife-i mahsusamiza devam etmekteyiz efendim. Berlin'e geleli üç kıta mektub gönderdim. Cevab alamadım. Çok misafir göndereceğiz. Fakat tamamen yol açılmadığından tehir olunuyor."13

sözleriyle hem hâlâ cevap beklediğini ve hem de Tatarlanın gönderilmesinde müşkilat olduğunu ortaya koymaktadır.

Osmanlı Devleti'nin Berlin Ataşemiliteri de 10.12.1915 tarihli yazışmasında yapılan faaliyetlere ve gözlemlerine dair önemli bilgiler vermiştir:

"Bugün Cuma günü Müşir Fuad Paşa hazretleri ve maiyetindekilerle Islâm üserası ordugâhını ziyaret eyledim. Bu ordugâh iki klsımdır: Birisi Tatar ve Gürcülere mahsustur. Iki bini Gürcü mütebakiyesi Tatar olmak üzere 12.000

Ikinci kısımda: Hindli, Faslı, Tunuslu, Cezayirli olmak üzere 4.500 kişidir. Her iki kısma bir miralay kumanda ediyor.

Umum üsera bölük bölük barakalara taksim olunmustur. Tatar ve Gürcü üsera Rusya' dan esir edilmis olup kıyafetleri muntazamdır. Fransız ve Ingilizlerden alınan Arab ve Hindli esirlerin kıyafetleri gayr-ı muntazamdır ve bir çoğu millî kıyafetleriyle bulunuyorlar.

Ibtida Tatar ve Gürcülerin bulunduğu yere gidildi. Hazret-i hilafetpenahiden komisyon-ı mahsus mektubu tebliğ ve selam-ı padişaĥे ile tebşir eylendi. Önlerinden geçtiğimiz müddetçe kendilerine mahsus bir şive ve nida ile "padişahım çok yaşa" deniliyordu. Tatarların camiinde Cuma namazını eda ettik. Namazı müteakib imam efendi tarafindan vaz u nasihat verildi. Taraf-l aciziden dahi Çanakkale muharebesi tasvir edildi. Müsir Fuad Pasa tarafindan dahi mücahedenin kudsiyeti izah edilerek işbu üseradan memalik-i sahaneye gitmek isteyenlerin gidebileceği ve bunlardan arzu edenlerin muharebe-i cihadiyeye iştirak edebileceği ve kalmak isteyenlere arazi ve saire verilerek iskan ettirileceği beyan buyruldu. Bu beyanat ve izahat esnasında umum müteessir oluyordu. Ağlayanlara çok tesadüf olundu... çalıştıkları işlikler gezildi.

Bunu müteakib ikinci kısmın bulunduğu mahalle hareket olundu. Hindlilere bir Alman vasitasıly** Ingilizce, Arablara Müşir Fuad

13. K: 1846 , D: 83 , F: $1 / 34$.

* 1. Dünya Savaşı esnasında Türkler dil bilir-güvenilir eleman sağlamakta büyük bir sıkıntı çektiklerinden [bakınız: Vahdet Kelessyılmaz, "I. Dünya Savaşı'nda Ulusal Güvenlik ve Dil Bilir Eleman Thtiyacı", Askerî Tarih Bülteni, Y1l 25, S. 48 (Subat 2000), s. 143-148.] bir kısım esirlere bir Alman aracılığıyla Ingilizce hitap edilmiş olmasına şaşırmamak gerekir. Ayrıca aynı paragrafta geçen "Turku" sözünden nasıl bir sey kastedildiği tam olarak anlasslamamıștır. Ancak incelediğimiz belge bütününde Türklerin faaliyetleri karşısında Arapların katılımı, Tatarlara kıyasla pek az olduğundan burada bahsedilen sekiz yüz kişilik grubun -belki de Turku kelimesiyle ifade edilmeye çalıșılan- her hangi bir farklı özelliği olabileceği sanısı akla gelmektedir. Ayrıca bu anılan grubun Türkiye'ye gönderildiklerine ilişkin her hangi bir kayda da henüz tesadüf etmedim. 
Paşa tarafından Arapça izahat verildi. Bu Arablardan "Turku" denilen sekiz yüz kadar bir kuvvet mücahedeye hazırdır...

Tatarlar kısmında Ramazanof isminde mülazım nazar-l dikkatimi celbetti. Bu zabit muharebeye gitmeyi arzu ediyor. Gürcü dört zabit daha müheyyadır. Bu ziyaret üzerine memalik-i Osmaniyeye gitmeye çok taleb çıkacağı memuldur. Vakit buldukça tekrar ziyaret edeceğim. Ordugâh Berlin'den otomobil ile yarım saat mesafededir." 14

5 Kanun-1 Evvel 1331 (18 Aralı 1915) tarihinde Alimcan İdris, “Avusturya' nın Eger beldesinde kain karargâhta mütemekkin üsera-yl müslime hakkındaki meşhudat, icraat ve mülahazatına dair" bir layiha sunmuştur. Buna göre, 2 Eylül'de İstanbul'dan hareket ederek 16 Eylül'de karargâha ulaşmışlardır. Ancak kendilerinin ulaşmasından evvel, yalnızca yirmi üç Kafkasyalı ve on bin Tatar Müslüman esir toplanmış olmasına rağmen -bir kısmının çalıştırılmak üzere fabrikalara sevk edilmelerinden dolayı- görev yerine vardıklanı zaman 3.500 kişi kaldığını görmüșlerdir. Ayrıca Alimcan İdris "ifa-yl vazife esnasında hayli müskilata tesadüf ettim" diyerek birlikte görev yaptığ tarcaya hiç vâkıf olmadığından yakınmış, "onun işi namaz kıldırmaktan ibaret $i d i^{\prime \prime}$ cümlesiyle yükünün ağırlığını belirtmiş ve şu taleplerde bulunmuştur:

"1- Tatar olan veya Tatarcayı iyi bilen daha iki zatın karargâha izamı. Bunlardan birinin Almancaya vakıf olması pek faydalı olacağl gibi her ikisinin de münevverü'l efkâr fakat ahlaklı ve dindar zevat arasından intihabı. Çünkü fazla taassub üsera meyanında merkez-i hilafete karşı pek ziyade sui tesir icra ediyor.

2- Üsera-yı müslimenin birlikte toplattırılmast veya gidecek efendilerin o yerlerde hepsini ziyaret edebilmeleri için mezuniyet istihsali." 15

"Paşa Efendi Huzur-l Alilerine" yazmış olduğu 7 Kanun-1 Evvel 331 (20 Aralık 1915) tarihli istidasında Alimcan İdris, aslen Sibiryalı olduğunu, Buhara'da tahsilini ikmâl ettikten sonra İstanbul'a gelerek Darülfünun İlahiyat Şubesi'ni bitirmeye muvaffak olduğunu belirttikten sonra sözlerine şöyle devam etmiştir:

“...Bundan dört ay mukaddem sırf lütuf ve himmet-i âlileri sayesinde diğer ü̧̧ arkadaşım ile Avrupa' ya ikmâl-i tahsil için gitmek üzere iken Ağaoğlu Ahmed Beyefendinin delaleti üzerine... Teşkilât-ı Mahsûsa' dan aldığım talimat üzerine arkadaşlarımdan ayrllıp Avusturya'daki Müslüman esirleri karargâhına gittim. Ve iki

14. K: 1846, D: 83, F: 1/31-33 (Belirtilen tarihin efrenci olduğu 14.10.31 tarihli "manzur buyruldu" ifadesinin yer aldığı derkenardan kesin olarak anlaşılmaktadır).

15. K: $1846, \mathrm{D}: 83, \mathrm{~F}: 1 / 37$. 
buçuk ay mütemadiyen çalışarak vazifemi ifa ettim. Yalnız olduğumdan pek çok müşkilata da maruz kaldım. Çünkü her ne kadar bir arkadassım Hoca Ali Rıza Efendi var ise de Efendi Tatarca bilmediğinden tahmil-i vazife benim üzerime yüklendi. Ne yapıldıysa ben yaptım. Arkadaşımın işi namaz kıldırmaktan ibaret kaldı. Binaenaleyh tekrar üsera karargâhına gönderilmeyecek olursam Isviçre' ye gidip tahsile devam edebilmem için müsaade-i âlilerini istirham ederim.

Benim tahsilim Lozan Darülfünunu Felsefe Şubesi. Avusturya' daki üsera meselesi hakkında diğer tafsilat-l şifahiyeme her ne zaman lüzum görülürse emr ü ferman." 16

"Viyana Sefiri"nden "Harbiye Nezaret-i Celilesine" yapılan 7 Kanun-1 Evvel 1915 tarihli açıklama yaşanan sıkıntılanın kaynağını açıkça ortaya koymaktadır:

"Izam buyrulmus olan Ali Rıza Efendi ile Idris Alimcan Efendi arasında tahaddüs eden fikir ve içtihad ihtilafından dolayı her ikisinin birlikte ifa-yl vazife edebilmesi badema müskil görüldüğünden ve Ali Rıza Efendinin sıfat-l âliyesi hasebiyle burada kalması Müşir Devletlu Fuad Paşa Hazretlerince arzu edildiğinden Idris Efendiye üçüncü maaşı olan on beş lira ile avdet harcırahına mukabil ayrica on lira ita ve Dersaadete avdeti tensil olundu. Ihtilafat-l şahsiye ve ilmiyeden başka bir sebebe müstenid olmayan avdet mecburiyetinden dolayl mumaileyh hakkındaki teveccüh-i devletlerinin tağyirden masun kalmasını rica ederim." 17

Bir yandan Hoca Ali Rıza Efendi ve Alimcan İdris arasında ortaya çıkan anlaşmazlıkla kendisini gösteren önemli fikir ve yaklaşım farklılığı devam ederken öte yandan esir Müslümanların durumuna ilişkin Alman ve Avusturya makamlanyla temaslar da devam etmektedir.

16. K: 1846, D: $83, F: 1 / 48$ (Alimcan Idris'in bu yazışmasında verdiği adres: Sirkeci Meşrutiyet Oteli).

17. K: 1846, D: 83, F: 1/50. Sözü geçen fikir ve içtihad ihtilafının-Hoca Ali Rıza Tatar olmamakla beraber- Cedidci-Kadimci çekismesinin bir yansıması olduğu kanaatindeyiz (Bu çatıșma zeminin kökeni ve gelişimi için bakınız: Ahmet Kanlıdere, Reform Within Islâm, The Tajdid and Jadid Movement Among The Kazan Tatars (1809-1917) Concilation or Conflict?, Istanbul, 1997). Hoca Ali Riza'nın Tatarca bilip bilmemesi asıl sorun olmasa gerektir. Çünkü bu durum birlikte çalışabilmelerine kalıcı bir engel olusturamazdı. Kaldı ki faaliyete konu olan esirler arasında Kafkasyalılar da vardı. Bu nedenle, o dönemde pek tanınmıs ve saygın bir kişilik olan Müşir Fuad Paşa'nın "sıfat-1 âliyesi hasebiyle" Ali Rıza Efendinin kalmasın tercih etmesini kendisinin de Kafkasyalı olusundan cok Alimcan Idris'in algı, yaklaşım ve yaşayış farkına bağlamak daha yerinde olur. II. Dünya Savaşı yillarında benzer faaliyetlere yine Almanlarla işbirliği hâlinde fakat bu defa daha önemli bir pozisyonda katılan Alimcan Idris'in kisilik formasyonunda dinî etkinin pek fazla olduğu söylenemez (Alimcan Idris'in II. Dünya Savaşı'ndaki faaliyetleri için bakınız: Müstecip Ülküsal, Kırım Yolunda Bir Ömür, Ankara, 1999). 
Harbiye Nezaret-i Celilesi'ne 10 Kanun-1 Evvel (23 Aralık) günü gelen ve 13.10.31 (26 Aralık 1915) tarihinde manzur buyrulduğuna dair ibare taşıyan şifreli bir telgrafa göre; Müşir Fuad Paşa tarafından “...Müslüman olarak bin mevcudlu bir taburun melbusen ve mechuzen dört beş gün zarfinda yola çıkacağı misüllü simdilik mevcud olan on dört bin kişinin de ol suretle peyderpey sevk edileceği maruzdur." ${ }^{18}$ Fakat bu birkaç gün içinde yola çıkacağı arz edilen taburun Türkiye'ye gelişi ileride değinilecek belgelerden de anlaşılacağı üzere hiç de kolay ya da çabuk olmayacaktır. Ayrıca, anılan yazışmada Fuad Paşa on beş gün daha Viyana ve Berlin'de kalmaları gerektiğinden bahisle refakat memurlarının avdete paralan kalmadığ 1 için bir miktar akçenin havale edilmesi ricasına mecbur kaldığını da belirtmiştir.

Berlin Sefareti'nden (Hakkı Paşa'dan) gelen 26 Kanun-1 Evvel 915 tarihli telgraf Fuad Paşa ve yanındaki heyetin aslî işinin esirler olmamakla birlikte bu konuya ciddiyetle eğildiklerini ve önemli ve çarpıcı görüşler ortaya çıktığını belgelendirmekle dikkat çekmektedir:

“...Hey'et üsera-yl Islâmiyeye telkinat vazifesini dahi ifa ediyor. Erbab-l hirfet ve san'atın bizde yerleşmesini şumûl ve mahiyet itibariyle cihada iştirakten daha mühim gördügümden bu hususta gayret ediyorum. (Alman) Harbiye Nazırl ile bilmüzakere gerek cihad için gideceklerin gerek şimdiden yerlessecek erbab-l hirfet ve san' atın nâil olacakları müsaadâta dair ... bir varaka tanzim olundu. Sureti posta ile takdim ediliyor. Buna emir buyurulan mevada ilaveten buradan cihada gidenlerden gayrısının yani tüccardan tavattun edileceklerin hizmet-i askeriyeye alınmayacaklarına ve burada teehhül arzusunda bulunanların kendilerince bir gûna masrafi mûcib olmayarak teehhül ettirileceklerine dair fikralar ilave ettim..."19

Berlin Sefiri Hakkı Paşa Hazretlerine cevaben keşide kllınan 27 Kanun-ı Evvel 915 tarihli tel ile “...şimdilik bilhassa üsera-yı İslâmiyenin Memalik-i Osmaniyeye muhaceretini temin zımninda sarf-ı mesai buyrulması mercudur." 20 denilmesi Türk yönetiminin Hakkı Paşa'nın konuya yaklaşımını yadırgamadığını ve benimsediğini ortaya koyar.

Avusturya'nın İstanbul Ataşemiliterliğinden Başkumandan Vekili ve Harbiye Nazırı Enver Paşa'ya gönderilen 4 Kanun-1 Sani 915 (4 Ocak 1916) tarihli ve 540 numaralı cevap yazısından anlaşıldığına göre, Müslüman esirlere bir imam gönderilmesi hakkında 1915 yılının Temmuz ayında Avusturya Ataşemiliterliği nezdinde girişimde bulunulmuştur. Ataşemiliter Pomiankowiski tarafından belirtildigine göre,

“...Rus Müslüman üsera-yı harbiyesi Almanya’da olduğu gibi kısım-ı azimi itibarılla diğer Rus üserasından tefrik olunarak, bun-

18. K: 1846 , D: 120 , F: $1 / 29$.

19. K: $1846, \mathrm{D}: 120, \mathrm{~F}: 1 / 31$.

20. K: 1846 , D: $120, \mathrm{~F}: 1 / 32$. 
lar 9882 kişidir, iskanlarında Çerkeslerle Tatarların ayrı ayrı barakalarda iskanı dahi nazar-ı itibardan dûr tutulmamıştır." 21

Pomiankowiski* ayrica din işlerine de hassasiyet gösterdiklerini belirterek "Budapesste' de bulunan Cemiyet-i İslâmiye memur-l ruhanisi ve ora Darülfünun muallim muavinlerinden Abdüllatif Efendi" nin bu işlerle ilgilendiğinden bahsetmiştir. Ancak bu cevap yazısının bu kadar gecikmeyle ulaşması Avusturya makamlarının Türklerin böylesine önemli bir stratejik faaliyetine karşı kayıtsızlığının ya da hoşnutsuzluğunun bir işareti olarak değerlendirilebilir mi? Bu üzerinde dikkatle durulması gereken bir konudur. Illeride değinilecek olan bazı belgeler de Tatar esirler konusundaki Türk taleplerinin müttefiklerince hemen ve kolaylıkla yerine getirilmiş olmadığını göstermektedir.

Abdürreşid İbrahim 15 Kanun-1 Sani 331 efrenci (15 Ocak 1916) tarihli yazışmasında "Azizim Ali Bey" hitabıyla şunları söylemiştir:

"Evvelce arz olunduğu gibi tamamı bir tabur (1002) asker ihzar olunmus, sevk edilmek üzere dört göz ile intizar olunuyor. Her gün bir hafta sonra denilmekte. Yol da açıldı bakalım. Bunları elbette bir kışlada misafir etmek icab eder. Cihad diyerek gidecekler." 22

Alimcan İdris'in yeni bir yazışması bu defa Berlin'den gerçekleştirilmiştir. 22 Kanun-1 Sani 916 (22 Ocak 1916) tarihli bu yazışmada, Berlin'e gittiğini ve tesadüfen Abdüreșid İbrahim ile görüştügünü, O'nun isteğiyle Berlin'de kaldığını belirten Alimcan İdris, gerektiği takdirde "Eger"e dönmek için emre amade olduğunu da dile getirmiştir ${ }^{23}$.

Abdürreşid İbrahim'in 2 Şubat 1916 tarihli yazışmasında, yakın zamanda gönderilecek mücahitlerin iyi karşılanması ve kendi ailesine tahsis edilmiş olan altı liranın vaktinde gönderilmesinin tekrar tenbih edilmesi dileklerinden sonraki şu sözleri hâlâ yaşanmakta olan bir sıkıntının varlığına işaret etmektedir:

"Hâmil-i varaka efendiler hakkında lâzım olacak muaveneti buyurmanız matlubdur.Vazifelerini ihmal etmemişlerdir. Aleyhlerinde söylenmiş sözlerin isnadattan başka bir şey olmadığı görülmektedir." ${ }^{24}$

21. K: 1846, D: 83, F: $1 / 16$ (Bu tarihin efrenci olduğunu ve böylece 4 Ocak 1916 miladî tarihine tesadüf ettiğini düşünüyoruz. Bunun nedeni 1331 değil de 1915 tarihine yer verilmis olmasıdır. Ancak bu tarihin 17 Ocak 1916 olma ihtimâli de düșünülebilir).

* Pomiankowiski'nin basılmış olan anılarında bu konuya ışık tutacak her hangi bir ayrıntıya tesadüf edilmemiştir (Joseph Pomiankowiski, Osmanlı Imparatorluğu’nun Çöküșü, 1914-1918, I. Dünya Savașı, Çev. Kemal Turan, Istanbul, 1990).

22. K: 1846, D: $83, \mathrm{~F}: 1 / 43$.

23. K: $1846, \mathrm{D}: 83, \mathrm{~F}: 1 / 39$ (Bu tarih efrenci olmalıdır).

24. K: $1846, \mathrm{D}: 83$, F: $1 / 42$. 
Buradan ister asker olmak arzusunda ister amele olmak arzusunda gitsinler oraya vardıktan sonra yine sizin emrinize tâbi, nerede istihdam ederseniz kabul edilir." 30

Abdürreşid İbrahim'in 1srarla istediği şekilde hiç olmazsa daha önce sevkleri için hazırlık yapılmış olanlann getirilmesine çalışıldığına şüphe yoktur. Berlin sefaretine yazılan 11 Nisan 332 (24 Nisan 1916) tarihli şifreden bu yolda sonuç alınmaya çalışıldığı anlaşılmaktadır:

\begin{abstract}
“Üsera-yl Islâmiyenin cihada iștiraki hususunda Dersaadet' e celblerinden sarfınazar edildiğinden bu babda teşebbüsatta bulunulmaması ve Tatar ve Dağıstan ahalisinden olup ...evvelce tasarruf olunan efrad sevk olunacaktır. Celb olunacak efradın sevkleri Almanya Harbiye Nezareti Kısm-ı Siyasîsi müdiriyle kararlaştırılmustır." 31
\end{abstract}

Bütün bu girişimler sonucunda 1916 yılı Mayıs ayında bir miktar Tatar'ın daha Türkiye'ye sevk edildiği ve bunların Asya taburunda istihdam edilerek Türklerin safında özveriyle savaşa katıldıkları bilinmekte$\operatorname{dir}^{32}$. Asya Taburu olarak anılan bu grup evvelce değindiğimiz yazışmalarda, askerî düzende ve tam donanımlı olarak gelecekleri bildirilen fakat bir türlü yola çıkarılamayan kafile olmalıdır.

1916 yılı Mayıs ayı itibariyle Tatarlardan bin kadar kişi de Türkiye'ye getirtilerek Anadolu'nun değişik yerlerinde iskan edilmiş durumda idiler. "Teşkilât-ı Mahsûsa Riyaset-i Aliyesine" 16.3.32 (29 Mayıs 1916) tarihinde "Avusturya ve Almanya'dan Dersaadet'e celb edilip bera-yl iskan Memalik-i Osmaniye'ye sevk edilmis üsera-yı islâmiyenin ahvalini ve haklarında simdiye kadar ifa olunan muamelat ve muaveneti yakından tedkik etmek üzere... vuku bulan tefrişat binnetice arz olunur" ${ }^{33}$ ifadesinin ardından sunulan rapor şunları içermektedir:

Kayseri livası dahilindeki Müslüman esirler ilk varışlarında bir misafirhaneye ikamet ettirilmişler ve kendilerine gereken yardım sağlanmıştır. Niğgde livasına yerleştirilmiş olan Tatarlardan bir kısmı karşılaşılan sorunlardan dolayı "dükkan, hane, bă̆, bahçe, tarla mebzul olduğundan" Kayseri'ye naklettirilmişlerdir. Konya vilayeti, Nefs-i Karahisar-1 Sahib ve civar köyleri, Eskişehir sancağı ile Mahmudiye nahiyesi ile havalisi ve Sivrihisar kazası, Ankara vilayeti dahilindeki Haymana kazası ile Ak-

30. K: $1846, \mathrm{D}: 83, \mathrm{~F}: 1 / 57$.

31. K: $1846, \mathrm{D}: 83, \mathrm{~F}: 1 / 54$

32. Nadir Devlet, "I. Dünya Savası'nda Osmanlılar Safında Carpısan Türk-Tatar Askerleri (Asya Taburu), XIII. Türk Tarih Kongresi (4-8 Ekim 1999)'nde 8 Ekim 1999 Cuma günü saat 14.00'de II numaralı salonda sunulan bildiri (Prof. Dr. Abdülkadir Özcan'ın yönettiği bu oturumun sunulan bildiriyle ilgili tartışma kısmında bu satırların yazarı bizzat söz alarak birkaç dakika da olsa bu makalede zikredilen hususlara değinmiş̧tir).

33. K: $1846, \mathrm{D}: 83, \mathrm{~F}: 1 / 58-64$. 
dağmadeni, Bilecik, İzmit, Bursa ve civar köyleri ve Orhangazi kazası, Nefs-i Adana, Nefs-i Kozan, Dörtyol... Tatarlann iskan edildiği diğer yerlerdendir.

Denetlemelerden sağlanan sonuçlara göre, "Üsera-yı İslâmiyeden Kırım Tatarlarının Memalik-i Osmaniyeye celb ve cem ve iskanlarında memleketin menfaat göreceğine kanaat hasll olmustur". Ancak Avusturya ve Almanya'dan getirtilen üsera-yı İslâmiyeden Şimalî Rusya'dan yani Sibirya ve Kazan ve Samara ve Ufa'dan olanların durumu Cenubî Rusya'dan (Kırım*) olanlar gibi değildir: "Simalî Rusya' dan olan üserayı İslâmiyenin sevk olundukları mevakiden ahlaken, dinen makam-ı Hilafete emsali kadar merbutiyet-i kalbiye taşımadiklarl, işret ve sair ceraimi işlemekte oldukları..." tespit edilmiştir.

Teşkilât-1 Mahsûsa'dan, Üsera-yı İslâmiyenin teftişine memur binba\$̧1 yukarıdaki raporunun sonunda "Memalik-i Osmaniye'nin tasarruf kabul etmeyecek derecede muhtac olduğu anasırın celb ve iskan edilmesi fikir ve kanaatinde" olduğunu belirtmiştir.

Almanya'daki üsera-yı İslâmiye hakkında sunduğu 4 Temmuz 916 tarihli layihada ${ }^{34}$ Alimcan İdris'in bunlardan iki binini kalpleri sızlayan Müslümanlar olarak belirttikten başkaca diğerlerinin durumuna ilişkin olarak verdiği bilgiler de bu topluluğun Anadolu'da iskan edilmesinde sorunlar yaşanabileceğini teyit eder niteliktedir.

Geri kalan gönüllülerin de getirtilmesi için yapılan çalışmalar yine Cermenlerin engellemeleri sonucunda istenilen düzeyde verimli olamamıştır. Bu konuda Harbiye Nezaretinin bilgisi dahilinde Alman makamlarına müracaatlar yapılmış olduğu belgelerle sabittir ${ }^{35}$.

* Ortaylı'nın belirttiği üzere, bugünkü Türkiye sınırlan dışında kalan Türk dünyası ele alındığında; Kırım Osmanlı Imparatorluğu'nun imtiyazlı ve birleşik bir parçası olarak, diğer Türk ülkelerinden daha farklı bir durum arz eder: Kınım Osmanlı asırlarında adeta bir Rumeli ve Anadolu eyaleti gibi yerini almış; Türkiye sadece Kınm Hanlığı'nın yönetiminde değil ve fakat maarifte, hatta günlük yaşayış, mutfak ve adetlerde dahi kendini kuvvetle hissettirmistir. Esasen Küçük Kaynarca (1768) antlaşmasıyla Osmanlı Imparatorluğu dişında kalan ve bilahare Rusya tarafından ilhak edilen Kınm; Osmanlı satveti içinde bazı Anadolu vilayetlerinden önce yerini almıştır. Ústelik Rusya'ya ilhak edildikten (1783) sonra da Kırım'ın Türkiye ile iktisadîkültürel ilişkileri kesilmemiş, Istanbul'da eğitim görmek ve özellikle matbaanın yaygın kullanımından sonra fstanbul'da basılan kitaplan getirmek gibi alıșkanlıklar da devam etmiştir. Bu bağlamda Gaspıralı Ismail Bey'in Istanbul Türkçesini temel alan Tercüman gazetesini çıkarması ve tesadüf ve ne de çok orijinal bir buluştur; yalnızca akıllı ve sağduyulu bir aydının kosullara uyması ve geleneği izlemesidir (†lber Ortaylı, "Türkiye'de Kırımlı Aydınlar", adı geçen sempozyum, s. 453-457). Bu bağlamda, Kırım'la kültürel bütünleşme esaslı ve sürekli olduğundan aslen oralı olanların uyum sorunu yașamamalarını doğal karșılamak gerekir.

34. K: $1846, \mathrm{D}: 83$, F: 1/68-69.

35. K: 1846 , D: 83 , F: $1 / 70-71$. 
Küçük partiler hâlinde de olsa bir kısım Tatar daha Türkiye'ye getirtilebilmişse de "...memalik-i müstevliyeden pek ziyade mülteci vurud etmekte olup fikdan-l vesaitten naşi onların iskan ve iasselerine yetişilemezken haricden bu strada adam celbi muvafik olamayacağından ...memleketçe kendilerinden istifade pek de muhakkak ve memul olmayan..." ${ }^{36}$ kişilerin getirtilmesinden kaçınılması 1916 yazında Dahiliye NaZırı İsmail (Canbulat) tarafından rica olunmuştur. Bu ricaya ve gerekse Cermenlerden kaynaklanan güçlüklere rağmen Tatarların celbi hususundaki çalı̧̧malar belgelerin gösterdiği üzere devam ettirilmiştir. Berlin Ataşemiliterliğinden gönderilen bir şifreli telgraftan anlaşıldığına göre, Almanlar üseranın harpte kullanılmasının " hukuk-ı beyne' l-düvel ahkamlna mugayir" ${ }^{37}$ olduğunu da öne sürerek tutumlanını açıklamaya çalışmışlardır. Alman makamlarının bu yönde kaygılar ifade etmesinin samimiyetten uzaklığı savaşın genel akışı içindeki faaliyetler bütününden bellidir. Anlaşllan odur ki, Almanlar, Türklerin kendi soydaşlanıla ilgili olarak -tamamen kendi inisiyatifleriyle- çalışmalar yapmalarını kendi hesaplan bakımından desteklenmesi gerekli etkinliklerden saymadıklan gibi onları gücendirmemeye çalışarak türlü bahanelerle kösteklemişlerdir. Başkumandan Vekili Enver Paşa'nın Teşkilât-1 Mahsûsa'ya gönderdiği şu yazı bu konuda şüpheye yer bırakmamaktadır:

"Biz Tuttuğumuz Alman üserasını bila kayd u sart Almanya' ya veriyoruz ve Almanların bunları ne suretle kullanacaklarını sormuyoruz. Binaenaleyh Almanlar aldıkları Müslüman Tatar üserayı bize göndersinler ve bizim bunları ne yapacağımızı sormasınlar. General Losov'a bu yolda cevab verilmesini rica ederim. Bence bunların depo alaylarına tevzi olunarak bizim orduda istihdamlarında hiçbir mahzur yoktur." 38

\section{SONUÇ}

Birinci Dünya Savaşı esnasında gerek Kınm gerek Kazan ve gerekse Sibirya Tatarları arasından Rus ordusunda asker olarak istihdam edilip Avusturya-Macaristan ve Almanya cephelerine gönderilen askerlerden tutsak düşenler her iki ülkedeki esir kamplarında tutulurlarken -kendi r1zaları doğrultusunda- Türkiye'ye getirtilmeleri yolunda teklifler almışlardır. Türk makamlarının bu teklifleri soydaşları tarafından önemli ölçüde kabul görmüştür. Ancak Enver Paşa'nın Tatarlarla ilgili olarak Teşkilât-1 Mahsûsa bağlantılı faaliyetleri, umulan amaca ulaşmak yolunda içtenlikli bir müttefik desteği bulamamıştır. Cermenler müttefik olmalarının gerektirdiği münasebetleri sürdürmelerine rağmen türlü bahanelerle bu gönderme işlemlerini kösteklemişlerdir. Bu durumdan rahatsızlığını bizzat kendi

36. K: $1846, \mathrm{D}: 83, \mathrm{~F}: 1 / 72$

37. K: $1846, \mathrm{D}: 83, \mathrm{~F}: 1 / 76-78$.

38. K: $1846, \mathrm{D}: 83, \mathrm{~F}: 1 / 79$. 
beyanıyla sabit olan Enver Paşa'nın, Biz tuttuğumuz Alman esirleri kayıtsız şartsız Almanlara veriyoruz. Almanlar da aldıkları Müslüman Tatar esirleri bize göndersinler ve bunları ne yapacağımızı sormasınlar mealindeki sözleri, Türkleri ve Türklügü ancak kendi emperyal çıkarları açısından uygun bir kullanım şekli ve alanı bulunduğu ölçüde değerlendirdikleri anlaşılan Cermenler tarafından ağırdan alınarak, gönülsüzce yerine getirilmiş olsa gerektir. Çünkü Almanlar yalnızca kendi çıkarlan sağlayacak bir yol izlemişlerdir. Bu bağlamda Panislamizmi kendi amaçlarına ulaşmak yolunda değerlendiren Almanlar kendi çıkarlarına yaramadığı sürece Türklerin milliyetçi-Turancı yaklaşımlanına itibar etmemişlerdir.

Abdürreşid İbrahim'in Avrupalılar sahnesinde hiçbir işe basit gözüyle bakmanın caiz olmayacağın belirttikten sonra Cermenlerin Türkiye'ye karşı sadık olmakla birlikte siyasî çıkarlarından vaz geçmeyeceklerini dile getirerek gösterdiği gerçekçiliğin ardından, Zata sadakat cereyana mani değildir. Milletlerin düşünceleri hiçbir zaman bugün için olamaz. Elli sene yüz sene sonrasi için bugünkü gün bir vasıtadır demiş olması Türk tarafında olan bitenin farkında olanlanın varlığına şüphe bırakmaz.

Belgeler 1şı̆̆ında kesin olarak söylenebilecek olan bir husus da Türklerin soydaşları ve dindaşlan olarak gördükleri bu esirleri kalıcı olarak yerleştirmeyi iyi niyetle düşünmüş olmalarıdır. Hakkı Paşa tarafından, Meslek ve sanat erbabının Türkiye'ye yerleşmesinin kapsam ve mahiyet itibariyle cihada iştirakten daha önemli olarak görülmesi, cihada gidenlerden gayrısının askerî hizmete alınmayacaklarına ve Türkiye'de evlenmek isteyenlerin kendilerine hiç bir masraf gerektirmeyecek şekilde evlendirileceklerine ilişkin söz verilmiş olması kalıcı bir iskan tasarlandığının işareti ve aynı zamanda amaçlananın yalnızca savaşla sınırlı askerî bir kazanım elde etmekten ibaret olmadığının kanıtıdır. Fakat Osmanlı Devleti'nin savaş şartlanı içinde iyice kötüleşen malî ve iktisadî durumundan kaynaklanan -ve belgelere yansıyan- s1kıntılar Teşkilât-ı Mahsûsa tarafından Türkiye'ye getirtilerek Anadolu'nun muhtelif mahallerine yerleştirilen Tatarların ihtiyaçlarının karşılanmasında da kendisini göstermiştir. Ayrıca getirtilen bu Tatarlardan bir bölümü yeni yerleştikleri çevreye uyum sağlamakta zorluk çekmişlerdir. Cünküi insanların aynı kökten gelmeleri ya da aynı dine mensubiyetleri kadar yaşanılan coğrafya ve içinde büyüdükleri sosyo-kültürel çevre de uyum açısından önem taşır. Bu açıdan, uzun zaman Osmanlı coğrafyasının bir parçası olmus olan Kırım asıllılar ile ilgili önemli bir uyum sorunu gözükmezken, daha uzak coğrafyalardan olanlar bakımından böyle bir sorunun yaşanmış olmasını onların kültürel bütünleşmetoplumsallaşma süreçlerindeki farklılığın doğal bir sonucu olarak karşılamak gerekir. 
Alimcan İdris ile ilgili olarak yaşandığı anlaşılan ve şikâyet konusu olan fikir ve içtihat ihtilafi ise bu anılan kültürel bütünleşmetoplumsallaşma sürecinin çok ötesinde algı, anlayış ve yaklaşım farklılıklarıyla kendisini gösteren cedidcilik-kadimcilik çatışmasının değişik bir muhitte ve önemli bir stratejik faaliyette bile karşımıza çıan yansımalarından biridir: Alimcan İdris'in esir kampına yalnızca Tatar olan veya Tatarcayı iyi bilen iki kişinin daha gönderilmesini istemekle yetinmeyerek bunların aydın düşünceli olması gerektiğini çünkü fazla taassubun esirler arasında Hilafet merkezine karşı pek çok kötü etki yaptığını belirtmesi bu konuda şüpheye yer bırakmamaktadır. 